\title{
ERRATUM TO: THE INFLUENCE OF SILICA CALCINATION TEMPERATURE VARIATION TO THE HYDROPHOBICITY AND TRANSMITTANCE ON GLASS SUBSTRATE
}

\author{
Roihatur Rohmah $^{1 *}$, M. Zainuri ${ }^{2}$ \\ ${ }^{1}$ Department of Computer Systems, Universitas Nahdlatul Ulama Sunan Giri Bojonegoro \\ ${ }^{2}$ Department of Physics, Institut Teknologi Sepuluh Nopember Surabaya
}

Erratum to: Roihatur Rohmah, M. Zainuri. Jurnal Neutrino:Jurnal Fisika dan Aplikasinya. 2020 April: 12(2):49-56. (Doi: 10.18860/neu.v12i2.8208: The title "The Influence of Silica Calcination Temperature Variation to The Hydrophobicity and Transmittance on Glass Substrate" was deleted because it is the same as the author's thesis.

Therefore, the title was replaced with "Study of Hydrophobic Surface by Silica Calcination Temperature Variation."

Keyword: Dip Coating; Hydrophobic Surface; Silica; Water Contact Angle

*Corresponding author.

E-Mail: roihaturrohmah@gmail.com 